\title{
Hydroclimate reconstruction in Indonesia over the last centuries by stalagmite isotopic analyses
}

\author{
Yumiko Watanabe ${ }^{1}$, T. Tagami' ${ }^{1}$, S. Ohsawa ${ }^{2}$, K. Takemura $^{2}$ and S. Yoden ${ }^{1}$ \\ 'Division of Earth and Planetary Sciences, Graduate School of Science, Kyoto University, Japan; yumiko@kueps.kyoto-u.ac.jp \\ ${ }^{2}$ Institute for Geothermal Sciences, Graduate School of Science, Kyoto University, Japan
}

\section{Oxygen and carbon isotopic data from an Indonesian stalagmite help improve our understanding of past rainfall variation in the tropics.}

\section{Stalagmites as paleoclimate archives}

Stable isotopic records of stalagmites are a powerful tool to reconstruct past climate change because stalagmites yield continuous terrestrial paleoclimate records and can be dated accurately by the U-Th dating method (e.g. McDermott et al. 2004; Fairchild et al. 2006). Figure 1 shows the formation process of stalagmites. In the soil and upper epikarst, water is enriched with $\mathrm{pCO}_{2}$ derived from plant respiration and organic matter decay (Fairchild et al. 2006). During its percolation in the carbonate bedrock, water dissolves carbonate components and eventually reaches supersaturation. When the water emerges into a cave as dripwater, carbon dioxide is degassed into cave air and calcium carbonate precipitates, forming a speleothem. Under the formation process described above, stalagmites record fluctuations of rainfall and/or temperature on the land surface as variation in their $\delta^{18} \mathrm{O}$ and $\delta^{13} \mathrm{C}$ composition.

\section{Previous studies on stalagmites in Asia}

There are numerous studies based on $\delta^{18} \mathrm{O}$ and $\delta^{13} \mathrm{C}$ analyses of stalagmite investigating terrestrial climate changes on Milankovitch and millennial timescales (e.g. McDermott et al. 2001; Wang et al. 2001, 2008). In recent years, some stalagmite studies also focused on shorter timescales. Figure
2 shows stalagmite study sites in Asia targeting reconstructions of rainfall variation during the last 2000 years. Stalagmites collected in China, India and Thailand yield oxygen isotopic variations on subdecadal to subannual timescales (Zhang et al. 2008; Tan et al. 2009; Sinha et al. 2007, 2011; Cai et al. 2010). In these studies, oxygen isotopic variations in the stalagmites were generally interpreted as representing variability in monsoonal rainfall intensity, although the exact interpretation on the climatic causes for isotopic variations in precipitation were different at each study site (e.g. amount effect vs. source effect). While these studies provided important insight in the precipitation regime of southern and

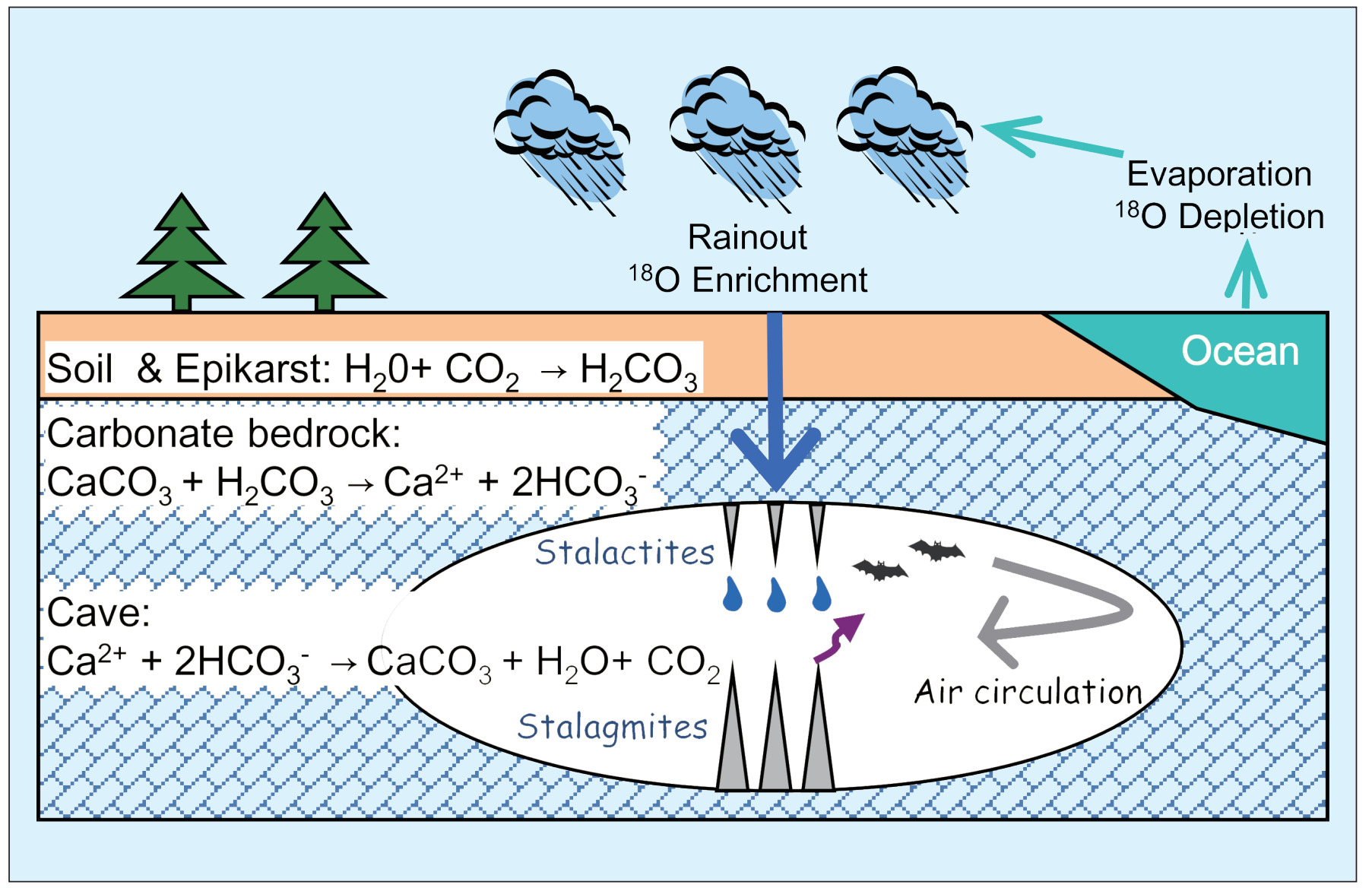

Figure 1:The formation process of stalagmites. 
eastern Asia, little attention has been paid to the southeastern Asian tropical regions.

\section{Our stalagmite study in Indonesia}

The high insolation in the tropics is the driving force of poleward heat transport, and tropical climate anomalies, such as El Niño and La Niña events, also affect the rest of the world through teleconnection. Thus the tropics are a critical region to study the global climate system. However, instrumental meteorological data are very limited compared to Europe and eastern North America (Parker et al. 2000) and need to be supplemented by proxy records. In our study, we performed a systematic comparison between variations in precipitation amount and $\delta^{18} \mathrm{O}$ and $\delta{ }^{13} \mathrm{C}$ measurements of an Indonesian stalagmite to reconstruct rainfall variability over the last 500 years.

First, we analyzed a stalagmite collected in the Ciawitali Cave in western Java and compared its $\delta^{18} \mathrm{O}$ and $\delta^{13} \mathrm{C}$ records with available instrumental rainfall records back to the 1950s. Negative correlations were statistically significant $\left(r^{2}=0.50\right.$ for $\delta^{18} \mathrm{O} ; r^{2}=0.85$ for $\delta^{13} \mathrm{C}$; Watanabe et al. 2010) and suggest that isotopic ratios of stalagmites are useful proxies for reconstructing rainfall amounts in the region. To account for the time lag of the water percolation from the land surface into the cave, we measured the percolation time of dripwater in the Ciawitali Cave by the ${ }^{3} \mathrm{H}-{ }^{3} \mathrm{He}$ dating method (Yamada et al. 2008). We obtained a percolation time of ca. 13 years. Taking this into account, the negative correlation disappears between the isotopic data and the instrumental rainfall record. This suggests that the $\delta^{18} \mathrm{O}$ and $\delta^{13} \mathrm{C}$ values of the stalagmite are immediately influenced by the climatic conditions outside the cave, probably via the piston-flow mechanism of groundwater and in-situ $\mathrm{CO}_{2}$ degassing described by Watanabe et al. (2010).

In addition, we measured $\delta^{18} \mathrm{O}$ and $\delta^{13} \mathrm{C}$ values over the last 500 years (1440-2006 AD) and found that $\delta^{18} \mathrm{O}$ and $\delta^{13} \mathrm{C}$ varied from -7.7 to $-5.4 \%$ o and from -14.1 to $-11 \%$, respectively. The $\delta^{18} \mathrm{O}$ and $\delta^{13} \mathrm{C}$ variations show synchronous changes throughout the entire period. Enriched ${ }^{18} \mathrm{O}$ signatures around 1600, 1800 and 1990 AD suggest episodes with drier conditions. These episodes coincide with evidence

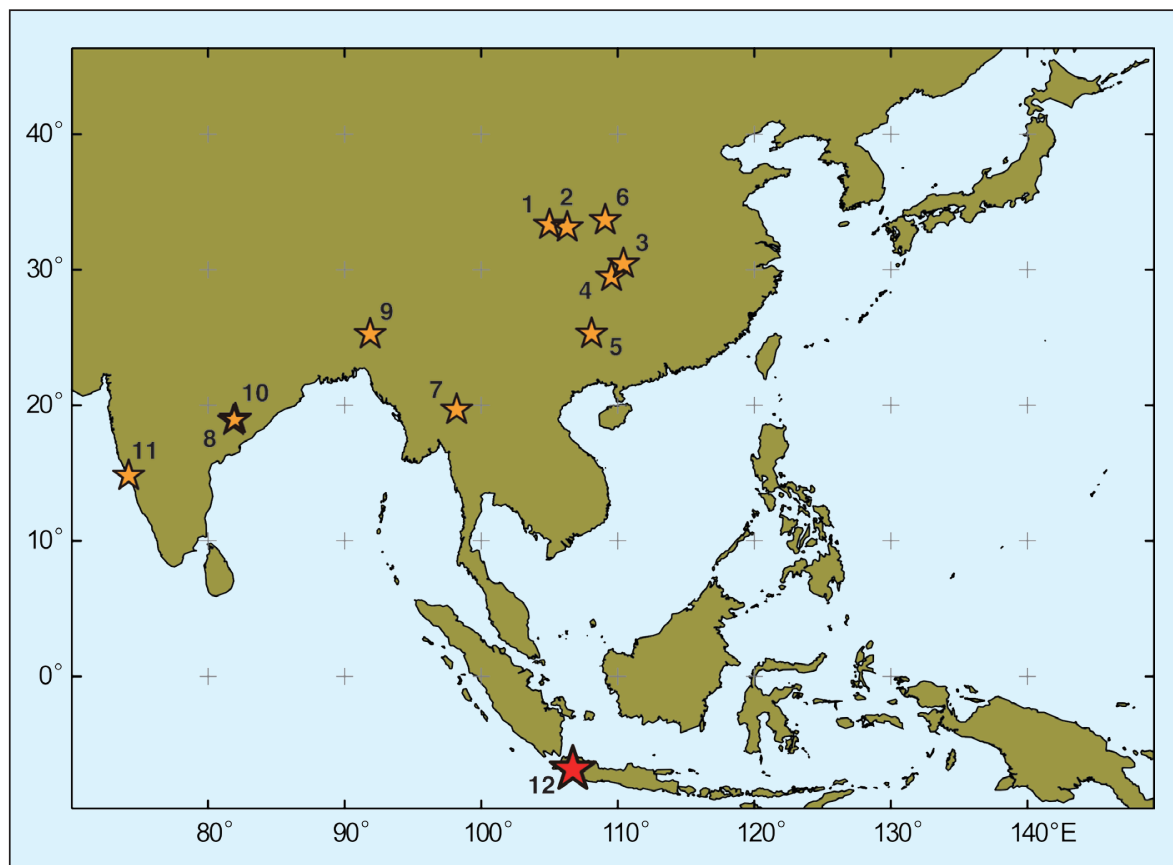

\begin{tabular}{|c|c|c|c|c|c|c|c|}
\hline No. & Country & Location & Elevation & Cave name & Duration & $\begin{array}{l}\text { Time- } \\
\text { resoluti } \\
\text { on }\end{array}$ & Reference \\
\hline 1 & China & $\begin{array}{l}33^{\circ} 19^{`} \mathrm{~N} \\
105^{\circ} 00^{\circ} \mathrm{E}\end{array}$ & $1200 \mathrm{~m}$ & Wanxiang & $\begin{array}{l}\text { 192-2003 } \\
\text { A.D. }\end{array}$ & $2.5 \mathrm{yr}$ & $\begin{array}{l}\text { Zhang et al. } \\
\text { (2008) }\end{array}$ \\
\hline 2 & China & $\begin{array}{c}33^{\circ} 08^{\prime} \mathrm{N} \\
106^{\circ} 18^{\prime} \mathrm{E}\end{array}$ & $870 \mathrm{~m}$ & Dayu & $\begin{array}{c}\text { 1249-1983 } \\
\text { A.D. }\end{array}$ & $\begin{array}{c}0.5 / 2-4 \\
y r\end{array}$ & $\begin{array}{l}\text { Tan et al. } \\
\text { (2009) }\end{array}$ \\
\hline 3 & China & $\begin{array}{c}30^{\circ} 27^{\prime} \mathrm{N} \\
110^{\circ} 25^{\prime} \mathrm{E}\end{array}$ & $294 \mathrm{~m}$ & Heshang & $\begin{array}{l}9450 \text { yr BP- } \\
2001 \text { A.D. }\end{array}$ & $\begin{array}{c}2 / 16 \\
y r\end{array}$ & $\begin{array}{l}\text { Hu et al. } \\
\text { (2008) }\end{array}$ \\
\hline 4 & China & $\begin{array}{c}29^{\circ} 29^{\prime} \mathrm{N} \\
109^{\circ} 32^{\prime} 45^{\prime \prime} \mathrm{E}\end{array}$ & $455 \mathrm{~m}$ & Lianhua & $\begin{array}{c}6590 \text { yr BP- } \\
\text { present }\end{array}$ & $\begin{array}{c}1-2 / 8 \\
y r\end{array}$ & $\begin{array}{l}\text { Cosford et al. } \\
\quad(2008)\end{array}$ \\
\hline 5 & China & $\begin{array}{l}25^{\circ} 17^{\prime} \mathrm{N} \\
108^{\circ} 5^{\prime} \mathrm{E}\end{array}$ & $680 \mathrm{~m}$ & Dongge & $\begin{array}{c}9000 \text { yr BP - } \\
2002 \text { A.D. }\end{array}$ & $4.5 \mathrm{yr}$ & $\begin{array}{l}\text { Wang et al. } \\
(2005)\end{array}$ \\
\hline 6 & China & $\begin{array}{c}33^{\circ} 40^{\prime} \mathrm{N} \\
109^{\circ} 05^{\prime} \mathrm{E}\end{array}$ & $500 \mathrm{~m}$ & Buddha & $\begin{array}{c}1270 \text { yr BP- } \\
\text { present }\end{array}$ & $1-3 \mathrm{yr}$ & $\begin{array}{l}\text { Paulsen et al. } \\
\quad(2003)\end{array}$ \\
\hline 7 & Thailand & $\begin{array}{l}19^{\circ} 40^{\prime} 30^{\prime \prime} \mathrm{N} \\
98^{\circ} 12^{\prime} 12^{\prime \prime} \mathrm{E}\end{array}$ & $923 \mathrm{~m}$ & Namjang & $\begin{array}{c}1900-2005 \\
\text { A.D. }\end{array}$ & $0.2-1 \mathrm{yr}$ & $\begin{array}{l}\text { Cai et al. } \\
(2010)\end{array}$ \\
\hline 8 & India & $\begin{array}{l}18^{\circ} 52^{\prime} \mathrm{N} \\
81^{\circ} 52^{\prime} \mathrm{E}\end{array}$ & $600 \mathrm{~m}$ & Jhumar & $\begin{array}{c}1075-2008 \\
\text { A.D. }\end{array}$ & $1.45 \mathrm{yr}$ & $\begin{array}{l}\text { Sinha et al. } \\
\text { (2011) }\end{array}$ \\
\hline 9 & India & $\begin{array}{l}25^{\circ} 15^{\prime} \mathrm{N} \\
91^{\circ} 52^{\prime} \mathrm{E}\end{array}$ & $1290 \mathrm{~m}$ & Wah Shikar & $\begin{array}{c}\text { 1399-2007 } \\
\text { A.D. }\end{array}$ & $0.97 \mathrm{yr}$ & $\begin{array}{l}\text { Sinha et al. } \\
\text { (2011) }\end{array}$ \\
\hline 10 & India & $\begin{array}{l}19^{\circ} 00^{\prime} \mathrm{N} \\
82^{\circ} 00^{\prime} \mathrm{E}\end{array}$ & $400 \mathrm{~m}$ & Dandak & $\begin{array}{l}600-1500 \\
\text { A.D. }\end{array}$ & $\begin{array}{c}0.4 / 2.7 \\
y r\end{array}$ & $\begin{array}{l}\text { Sinha et al. } \\
(2007)\end{array}$ \\
\hline 11 & India & $\begin{array}{l}14^{\circ} 16^{\prime} \mathrm{N} \\
75^{\circ} 08^{\prime} \mathrm{E}\end{array}$ & $600 \mathrm{~m}$ & Akalagavi & $\begin{array}{c}\text { 1666-1996 } \\
\text { A.D. }\end{array}$ & $1.1 \mathrm{yr}$ & $\begin{array}{l}\text { Yadava et al. } \\
\quad(2004)\end{array}$ \\
\hline 12 & Indonesia & $\begin{array}{c}7^{\circ} 02^{\prime} \mathrm{S} \\
106^{\circ} 55^{\prime} \mathrm{E}\end{array}$ & $750 m$ & Ciawitali & $\begin{array}{l}\text { 1963-2006 } \\
\text { A.D. }\end{array}$ & $1.1 \mathrm{yr}$ & $\begin{array}{l}\text { Watanabe et } \\
\text { al. (2010) }\end{array}$ \\
\hline
\end{tabular}

Figure 2: Study sites of Asian stalagmites used to reconstruct rainfall variations over the last 2000 years. The red star shows the location of the Ciawitali Cave on West Java, Indonesia.

of droughts documented in lake sediments of East Java (Rodysill et al. 2011), and hence are likely associated with regional hydrologic anomalies caused by ENSO dynamics.

Further $\delta^{18} \mathrm{O}$ and $\delta^{13} \mathrm{C}$ measurements are in progress to reconstruct rainfall anomalies in the Asian tropics during the past millennium, especially during the Medieval Climate Anomaly and Little Ice Age.

\section{Selected references}

Full reference list online under:

http://www.pages-igbp.org/products/newsletters/ref2012_2.pdf

Cai B et al. (2010) Journal of Geophysical Research 115, doi: 10.1029/2009J0013378

Sinha A et al. (2011) Geophysical Research Letters 38, doi: 10.1029/2011GL047713

Watanabe $Y$ et al. (2010) Palaeogeography, Palaeoodimatology, Palaeoecology 293: 90-97

Yamada M (2008) Geophysical Research Letters 35, doi: 10.1029/2008GL033237

Zhang P (2008) Science 322: 940-942 